European Journal of Pharmacology, 32 (1975) 349-356

(c) North-Holland Publishing Company, Amsterdam - Printed in The Netherlands

\title{
THE POSITIVE INOTROPIC EFFECT OF GLUCAGON IN THE CHRONICALLY FAILED RIGHT VENTRICLE AS DEMONSTRATED IN THE ISOLATED CAT HEART*
}

\author{
STEVEN WINOKUR, NANCY L. NOBEL-ALLEN and BENEDICT R. LUCCHESI \\ The University of Michigan Medical School, Department of Pharmacology, Ann Arbor, Michigan 48104, U.S.A.
}

Received 16 December 1974, revised MS received 3 March 1975, accepted 8 April 1975

S. WINOKUR, N.L. NOBEL-ALLEN and B.R. LUCCHESI, The positive inotropic effect of glucagon in the chronically failed right ventricle as demonstrated in the isolated cat heart, European J. Pharmacol. 32 (1975) 349-356.

Previous in vitro studies had provided evidence to show that papillary muscles obtained from cats with chronic right ventricular failure had lost their ability to develop a positive inotropic response to glucagon. Since it is difficult to extrapolate from the isolated papillary muscle to the intact heart, studies were done to assess the effects of glucagon in the perfused isovolumically beating heart obtained from cats four months after surgical banding of the pulmonary artery for the experimental production of chronic right ventricular failure (CRVF). At the peak of the dose-response curve, glucagon increased right ventricular isovolumic pressure $25 \%(39.00 \pm 4.37$ to $49.67 \pm 5.15 \mathrm{~mm} \mathrm{Hg} ; p<0.001)$ and right ventricular $\mathrm{dP} / \mathrm{dt} 63 \%(522.2 \pm 93.9$ to $852.6 \pm 159.9 \mathrm{~mm} \mathrm{Hg} / \mathrm{sec}$; $p<0.001$ ) in 6 normal hearts. Similar dose related increases in right ventricular isovolumic pressure and $\mathrm{dP} / \mathrm{dt}$ were obtained in 6 hearts taken from cats with chronic right ventricular failure. The respective increases in right ventricular isovolumic pressure and $\mathrm{dP} / \mathrm{dt}$ were $43 \%(30.33 \pm 4.01$ to $43.67 \pm 6.25 \mathrm{~mm} \mathrm{Hg} ; p<0.025)$ and $73 \%$ $(317.50 \pm 30.29$ to $550.83 \pm 89.04 \mathrm{~mm} \mathrm{Hg} / \mathrm{sec} ; p<0.025)$. These results provide evidence that glucagon possesses the capacity to augment myocardial contractility in the heart with experimentally induced chronic right ventricular failure.

Ventricular isovolumic pressure

Ventricular contractility
Heart failure Isoproterenol Ventricular $\mathrm{dP} / \mathrm{dt}$

\section{Introduction}

The polypeptide hormone, glucagon, has been reported to possess a marked positive inotropic effect on isolated cardiac muscle (Farah and Tuttle, 1960; Glick et al., 1968; Lucchesi, 1968), in intact animals (Glick et al., 1968; Lucchesi, 1968) and in patients with impaired cardiac function (Brogan et al., 1969; Vaughn et al., 1970; Wilcken and Lvoff, 1970; Siegel et al., 1970; Lvoff and Wilcken, 1972). There is some uncertainty, however, concerning the effectiveness of glucagon in the management of patients with chronic cardiac decom-

\footnotetext{
* This study was supported by a Research Grant from the Michigan Heart Association.
}

pensation (Williams et al., 1969; Greenberg et al., 1970; Smithen et al., 1972). The disparate findings could be related to the heterogeneous patient population studied or to the varied modes of drug administration and dosage regimens employed. The possibility that patient selection might be of importance was emphasized by the experimental studies of Gold et al. (1970) in which it was shown that papillary muscles taken from cats in right ventricular failure produced by pulmonary arterial banding did not respond to glucagon either by an increase in inotropism or by an increase in adenyl cyclase activity; these same papillary muscles, however, could still respond to catecholamines. Goldstein et al. (1971) and Prasad (1972) observed that glucagon did not produce 
a positive inotropic response in human papillary muscles obtained from patients with chronic heart failure. On the other hand, Strauer (1971) has reported that glucagon produces a positive inotropic effect in human papillary muscles obtained at the time of mitral valve replacement from patients with chronic congestive heart failure. Recent studies in the intact cat in which chronic right ventricular failure was produced by surgical banding of the pulmonary artery, revealed that glucagon was capable of augmenting myocardial function (Nobel-Allen et al., 1973). Since it is well recognized that there are inherent limitations in studies performed on intact hearts in vivo, the present investigation was conducted in the cat isolated heart which had been subjected to chronic outflow obstruction by surgical banding of the pulmonary artery. The results of this investigation provide evidence that glucagon possesses the capacity to augment myocardial contractility in hearts obtained from cats with experimentally induced chronic right ventricular failure.

\section{Materials and methods}

Hearts from 6 normal cats and 6 cats with right ventricular hypertrophy and chronic right ventricular failure were studied. Hypertrophy and failure were produced in 6 adult cats (4.6-5.2 kg in weight) by constriction of the main pulmonary artery, according to the procedure described by Spann et al. (1967).

4 months later (exactly 120 days), the animals were studied along with 6 normal cats which served as controls. At the time of study, the cats were anesthetized with pentobarbitalsodium, $30 \mathrm{mg} / \mathrm{kg}$ i.v. and respired by means of a Harvard respirator. A cannula was placed in the abdominal aorta through the femoral artery, the heart rate was recorded by means of a tachograph triggered from the Lead II ECG and a cannula was placed in the right atrium through the right jugular vein. Cardiac output was determined by the indicator-dilution technique (Columbus Instruments Cardiac Output
Computer) with injection of $1.25 \mathrm{mg}$ indocyanine $(1 \mathrm{ml})$ into the right atrium and sampling of up to $10 \mathrm{ml}$ from the abdominal aorta at a rate of $15 \mathrm{ml} / \mathrm{min}$.

After the cardiac output measurements were made, the chest was opened and a 20 -gauge, thin wall needle was inserted through the free wall of the right ventricle and attached directly to a Statham $23 \mathrm{Db}$ transducer. The zero reference point was the mid-right ventricular level. High- and low-gain right ventricular pressure was measured.

On conclusion of these studies the hearts were excised rapidly and placed in cold buffer, after which they were tied on to a perfusing cannula; perfusion via the aorta was instituted immediately at a constant pressure of $90 \mathrm{~mm}$ $\mathrm{Hg}$. The perfusion medium was contained in a double-walled chamber which was buffered with $95 \%$ oxygen $-5 \%$ carbon dioxide. The pressure within the reservoir was maintained constant at $90 \mathrm{~mm} \mathrm{Hg}$ by connecting it to a pressure stabilizer (Beck, 1958). Water from a thermostatically controlled water bath circulated through the outer jackets of the glass reservoir, heat exchangers and the chamber in which the heart was contained. The temperature of the perfusion medium just above the point at which it entered the aorta was maintained at $37^{\circ} \mathrm{C}$ and was not allowed to recirculate. A thin Latex balloon was inserted through the tricuspid valve into the right ventricular cavity and filled with water to give a constant internal ventricular volume. The hearts were paced through intramural right ventricular electrodes connected to a Grass SD5 stimulator. Hearts were paced at a rate of $90 \mathrm{bpm}$. The intraventricular balloon was attached directly to a Statham $23 \mathrm{Db}$ pressure transducer from which the isovolumic right ventricular pressure, in $\mathrm{mm} \mathrm{Hg}$, and the peak rate of pressure development, $\mathrm{dP} / \mathrm{dt}$, in $\mathrm{mm} \mathrm{Hg} / \mathrm{sec}$, was obtained by electronic differentiation. The buffer medium contained $(\mathrm{mM}): 142.6$ sodium, 5.9 potassium, 2.5 calcium, 1.2 magnesium, 126 chloride, 1.2 monobasic phosphate, 25 bicarbonate, and 5 dextrose at $\mathrm{pH} 7.4$.

The hearts were allowed to stabilize for 30 
min after which drugs were administered as bolus injections made directly above the aortic cannula. All drugs were prepared immediately before use and were dissolved in buffer medium. Each dose of drug was administered when the previous injection of a particular agent had produced its maximum response. Thus, cumulative dose--response curves for glucagon (10$160 \mu \mathrm{g})$ and isoproterenol $(0.05-0.10 \mu \mathrm{g})$ were carried out in each heart.

Upon completion of the study, the total heart weight was obtained as well as the weight of the free wall of the right ventricle and right ventricular wall thickness was measured. The interventricular septum was then weighed together with the left ventricle.

All values are expressed as the mean \pm their standard error (S.E.). Data were analyzed by Student's $t$-test for self-paired and grouped analysis, whichever was applicable.

\section{Results}

3.1. Hemodynamic findings in normal cats compared to cats with chronic right ventricular failure (CRVF)

The 6 normal cats (controls) weighed $3.76 \pm$ $0.23 \mathrm{~kg}$; the right ventricular weights averaged $0.66 \pm 0.04 \mathrm{~g} / \mathrm{kg}$ body wt. and the right ventricular wall measured $2.34 \pm 0.05 \mathrm{~mm}$ in thickness. The 6 animals with $\mathrm{CRVF}$ weighed $4.65 \pm 0.12 \mathrm{~kg}$ and were studied exactly 120 days ( 4 months) after constriction of the pulmonary artery. In these 6 animals the right ventricular weight and wall thickness averaged $1.07 \pm 0.04 \mathrm{~g} / \mathrm{kg}$ body weight and $3.90 \pm 0.05$ $\mathrm{mm}$, respectively, both values being increased significantly in comparison with the control group ( $p<0.001$ and $p<0.001$ respectively).

Initial hemodynamic measurements obtained in both the normal cats and cats with CRVF are summarized in table 1 . In animals with CRVF, peak right ventricular pressure exceeded twice the control values $18.8 \pm 4.2 \mathrm{vs}$. $47.3 \pm 4.6 \mathrm{~mm} \mathrm{Hg}(p<0.001)$. The mean heart rates did not differ significantly between the two groups $(p>0.2)$. The cardiac index was reduced significantly in the CRVF group when compared to controls $-144.7 \pm 16.0 \mathrm{ml} / \mathrm{min} /$ $\mathrm{kg}$ in the normal cats vs. $99.5 \pm 10.6 \mathrm{ml} / \mathrm{min} / \mathrm{kg}$ in the CRVF group ( $p<0.05)$. All animals in the CRVF group had evidence of pleural effusion and 4 of the 6 CRVF cats had hepatomegaly and ascites. Right ventricular end-diastolic pressure was elevated significantly in the CRVF group as compared to the controls, $4.2 \pm 0.5$ $\mathrm{mm} \mathrm{Hg}$ vs. $1.8 \pm 0.5 \mathrm{~mm} \mathrm{Hg}(p<0.01)$.

\subsection{Effects of glucagon on the normal cat heart} and on hearts from animals with chronic right ventricular failure

Glucagon produced a dose-related augmentation of right ventricular isovolumic pressure and right ventricular $\mathrm{dP} / \mathrm{dt}$ in all of the hearts from the normal group. At peak effect, right ventricular isovolumic pressure increased $25 \%$ from a control value of $39.00 \pm 4.37$ to $49.67 \pm$ $5.15 \mathrm{~mm} \mathrm{Hg}(p<0.001)$. The augmentation of right ventricular contractility was accompanied by a dose-related increase in right ventricular $\mathrm{dP} / \mathrm{dt}$ which, at peak effect, rose $63 \%$ from a control value of $522.2 \pm 93.9$ to $852.6 \pm 159.9$ $\mathrm{mm} \mathrm{Hg} / \mathrm{sec}(p<0.001)$. In the 6 hearts with chronic right ventricular failure, glucagon produced a similar dose-related increase in right ventricular isovolumic pressure from a control of $30.33 \pm 4.01$ to a peak value of $43.67 \pm 6.25$ $\mathrm{mm} \mathrm{Hg} \mathrm{(} 43 \%$ increase from control; $p<0.025$ ). Right ventricular $\mathrm{dP} / \mathrm{dt}$, likewise, increased $73 \%$ in response to glucagon from a control value of $317.50 \pm 30.29 \mathrm{~mm} \mathrm{Hg} / \mathrm{sec}$ to a peak value of $550.83 \pm 89.04 \mathrm{~mm} \mathrm{Hg} / \mathrm{sec}(p<$ 0.025 ). The data from both groups are summarized in tables 2 and 3 . The results obtained in the two groups of perfused isolated hearts show that glucagon caused substantial increases in right ventricular isovolumic pressure and right ventricular $\mathrm{dP} / \mathrm{dt}$ in both normal hearts and hearts with chronic right ventricular failure.

\subsection{Response to isoproterenol}

Isoproterenol caused a dose-related increase in right ventricular isovolumic pressure and 


\section{TABLE 1}

Hemodynamic and anatomical data of normal hearts vs. hearts from CRVF group.

\begin{tabular}{|c|c|c|c|c|c|c|c|c|}
\hline Group & $n$ & Weight (kg) & $\begin{array}{l}\text { Heart rate } \\
\text { (bpm) }\end{array}$ & \multicolumn{2}{|c|}{$\begin{array}{l}\text { Peak RV } \\
\text { pressure (mm Hg) }\end{array}$} & \multicolumn{2}{|c|}{$\begin{array}{l}\mathrm{RV} \text { end-diastolic } \\
\text { pressure }(\mathrm{mm} \mathrm{Hg})\end{array}$} & $\begin{array}{l}\text { Cardiac index } \\
(\mathrm{ml} / \mathrm{min} / \mathrm{kg} \\
\text { body weight) }\end{array}$ \\
\hline Normal & 6 & $3.76 \pm 0.23$ & $142.5 \pm 7.2$ & $18.6 \pm 4.2$ & & $1.8 \pm 0.5$ & & $144.7 \pm 16.0$ \\
\hline CRVF & 6 & $4.65 \pm 0.12$ & $155.0 \pm 7.6$ & $47.3 \pm 4.6$ & & $4.2 \pm 0.5$ & & $99.5 \pm 10.6$ \\
\hline$p$ & & $<0.025$ & $>0.2$ & $<0.001$ & & $<0.01$ & & $<0.05$ \\
\hline \multirow[t]{2}{*}{ Group } & \multirow[t]{2}{*}{$n$} & \multirow{2}{*}{$\begin{array}{l}\text { Stroke volume } \\
\text { (ml/beat) }\end{array}$} & \multicolumn{4}{|c|}{ Right ventricular weight } & \multirow{2}{*}{\multicolumn{2}{|c|}{$\begin{array}{l}\text { RV wall thickness } \\
(\mathrm{mm})\end{array}$}} \\
\hline & & & \multicolumn{2}{|c|}{$\%$ of whole heart weight } & \multicolumn{2}{|c|}{$\mathrm{g} / \mathrm{kg}$ body weight } & & \\
\hline Normal & 6 & $3.9 \pm 0.5$ & \multicolumn{2}{|l|}{$12.4 \pm 0.7$} & \multicolumn{2}{|c|}{$0.66 \pm 0.04$} & \multicolumn{2}{|c|}{$2.34 \pm 0.05$} \\
\hline CRVF & 6 & $3.1 \pm 0.2$ & \multicolumn{2}{|l|}{$21.5 \pm 0.6$} & \multicolumn{2}{|c|}{$1.07 \pm 0.04$} & \multicolumn{2}{|c|}{$3.90 \pm 0.05$} \\
\hline$p$ & & $>0.2$ & \multicolumn{2}{|l|}{$<0.001$} & $<0.0$ & & \multicolumn{2}{|c|}{$<0.001$} \\
\hline
\end{tabular}

TABLE 2

Right ventricular isovolumic pressure response to glucagon in normal and CRVF hearts.

\begin{tabular}{|c|c|c|c|c|c|c|c|}
\hline \multirow[t]{3}{*}{ Group } & \multirow[t]{3}{*}{$n$} & \multicolumn{5}{|c|}{ Right ventricular isovolumic pressure ( $\mathrm{mm} \mathrm{Hg}$ ) } & \\
\hline & & \multirow[t]{2}{*}{ Control } & \multicolumn{3}{|c|}{ Dose of glucagon $(\mu \mathrm{g})$} & \multirow[b]{2}{*}{80} & \multirow[b]{2}{*}{160} \\
\hline & & & 10 & 20 & 40 & & \\
\hline Normal & $\begin{array}{l}6 \\
p^{*}\end{array}$ & $39.00 \pm 4.37$ & $\begin{array}{l}44.50 \pm 3.80 \\
<0.05\end{array}$ & $\begin{array}{l}49.00 \pm 4.23 \\
<0.005\end{array}$ & $\begin{array}{l}49.67 \pm 4.87 \\
<0.001\end{array}$ & $\begin{array}{l}49.50 \pm 5.68 \\
<0.001\end{array}$ & $\begin{array}{l}49.67 \pm 5.15 \\
<0.001\end{array}$ \\
\hline CRVF & $\begin{array}{l}6 \\
p^{*}\end{array}$ & $30.33 \pm 4.01$ & $\begin{array}{l}34.67 \pm 5.12 \\
<0.025\end{array}$ & $\begin{array}{l}39.67 \pm 6.48 \\
<0.025\end{array}$ & $\begin{array}{l}43.50 \pm 7.42 \\
<0.025\end{array}$ & $\begin{array}{l}44.33 \pm 7.10 \\
<0.025\end{array}$ & $\begin{array}{l}43.67 \pm 6.25 \\
<0.025\end{array}$ \\
\hline
\end{tabular}

* Paired analysis, compared to respective control values.

\section{TABLE 3}

Right ventricular $\mathrm{dP} / \mathrm{dt}$ response to glucagon in normal and CRVF hearts.

\begin{tabular}{|c|c|c|c|c|}
\hline \multirow[t]{3}{*}{ Group } & \multirow[t]{3}{*}{$n$} & \multicolumn{3}{|c|}{ Right ventricular $\mathrm{dP} / \mathrm{dt}(\mathrm{mm} \mathrm{Hg} / \mathrm{sec})$} \\
\hline & & \multirow[t]{2}{*}{ Control } & \multicolumn{2}{|c|}{ Dose of glucagon $(\mu \mathrm{g})$} \\
\hline & & & 10 & 20 \\
\hline Normal & $\begin{array}{l}6 \\
p^{*}\end{array}$ & $522.17 \pm 93.88$ & $\begin{array}{l}625.33 \pm 102.76 \\
<0.01\end{array}$ & $\begin{array}{l}737.83 \pm 114.80 \\
<0.001\end{array}$ \\
\hline CRVF & $\begin{array}{l}6 \\
p^{*}\end{array}$ & $317.50 \pm 30.29$ & $\begin{array}{l}366.67 \pm 40.54 \\
<0.01\end{array}$ & $\begin{array}{l}443.33 \pm 66.71 \\
<0.025\end{array}$ \\
\hline
\end{tabular}

\footnotetext{
* Paired analysis, compared to respective control values.
} 
Table 3 (Continued)

\begin{tabular}{|c|c|c|c|c|c|}
\hline \multirow[t]{3}{*}{ Group } & \multirow[t]{3}{*}{$n$} & \multicolumn{4}{|c|}{ Right ventricular $\mathrm{dP} / \mathrm{dt}(\mathrm{mm} \mathrm{Hg} / \mathrm{sec})$} \\
\hline & & \multirow[t]{2}{*}{ Control } & \multicolumn{3}{|c|}{ Dose of glucagon $(\mu \mathrm{g})$} \\
\hline & & & 40 & 80 & 160 \\
\hline Normal & $\begin{array}{l}6 \\
p^{*}\end{array}$ & $522.17 \pm 93.88$ & $\begin{array}{l}823.50 \pm 124.91 \\
<0.001\end{array}$ & $\begin{array}{l}837.00 \pm 130.25 \\
<0.001\end{array}$ & $\begin{array}{l}852.56 \pm 159.96 \\
<0.001\end{array}$ \\
\hline CRVF & $\begin{array}{l}6 \\
p^{*}\end{array}$ & $317.50 \pm 30.29$ & $\begin{array}{l}511.00 \pm 86.01 \\
<0.025\end{array}$ & $\begin{array}{l}528.50 \pm \quad 80.59 \\
<0.025\end{array}$ & $\begin{array}{l}550.83 \pm 89.04 \\
<0.025\end{array}$ \\
\hline
\end{tabular}

* Paired analysis, compared to respective control values.

right ventricular $\mathrm{dP} / \mathrm{dt}$ in both the normal and CRVF group. The data are summarized in table 4 . The results from one experiment in a heart with chronic right ventricular failure are shown in fig. 1 in which isoproterenol and glucagon caused dose-related augmentation in inotropic activity. Even though glucagon is less effective than isoproterenol with respect to its ability to augment myocardial contractility, it should be noted that the polypeptide hormone has a duration of action which is greater than that of the catecholamine.

TABLE 4

Responses to isoproterenol in normal and CRVF hearts.

\begin{tabular}{|c|c|c|c|c|}
\hline \multirow[t]{3}{*}{ Group } & \multirow[t]{3}{*}{$n$} & \multicolumn{3}{|c|}{ Right ventricular isovolumic pressure $(\mathrm{mm} \mathrm{Hg})$} \\
\hline & & \multirow[t]{2}{*}{ Control } & \multicolumn{2}{|l|}{ Isoproterenol $(\mu \mathrm{g})$} \\
\hline & & & 0.05 & 0.10 \\
\hline Normal & $\begin{array}{l}6 \\
p^{*}\end{array}$ & $39.00 \pm 4.37$ & $\begin{array}{l}51.60 \pm 8.96 \\
<0.025\end{array}$ & $\begin{array}{l}60.83 \pm 8.01 \\
<0.005\end{array}$ \\
\hline CRVF & $p^{*}$ & $30.33 \pm 4.01$ & $\begin{array}{l}66.00 \pm 11.07 \\
<0.005\end{array}$ & $\begin{array}{l}64.17 \pm 7.75 \\
<0.005\end{array}$ \\
\hline \multirow[t]{3}{*}{ Group } & $n$ & \multicolumn{3}{|c|}{ Right ventricular $\mathrm{dP} / \mathrm{dt}(\mathrm{mm} \mathrm{Hg} / \mathrm{sec})$} \\
\hline & & \multirow[t]{2}{*}{ Control } & \multicolumn{2}{|l|}{ Isoproterenol $(\mu \mathrm{g})$} \\
\hline & & & 0.05 & 0.10 \\
\hline Normal & $\begin{array}{l}6 \\
p^{*}\end{array}$ & $522.17 \pm 93.88$ & $\begin{array}{l}985.00 \pm 191.45 \\
<0.025\end{array}$ & $\begin{array}{l}1205.67 \pm 175.67 \\
<0.005\end{array}$ \\
\hline CRVF & $\begin{array}{l}6 \\
p^{*}\end{array}$ & $317.5 \pm 30.29$ & $\begin{array}{l}918.17 \pm 186.92 \\
<0.025\end{array}$ & $\begin{array}{l}973.00 \pm 143.79 \\
<0.005\end{array}$ \\
\hline
\end{tabular}

\footnotetext{
* Paired analysis, compared to respective control values.
} 


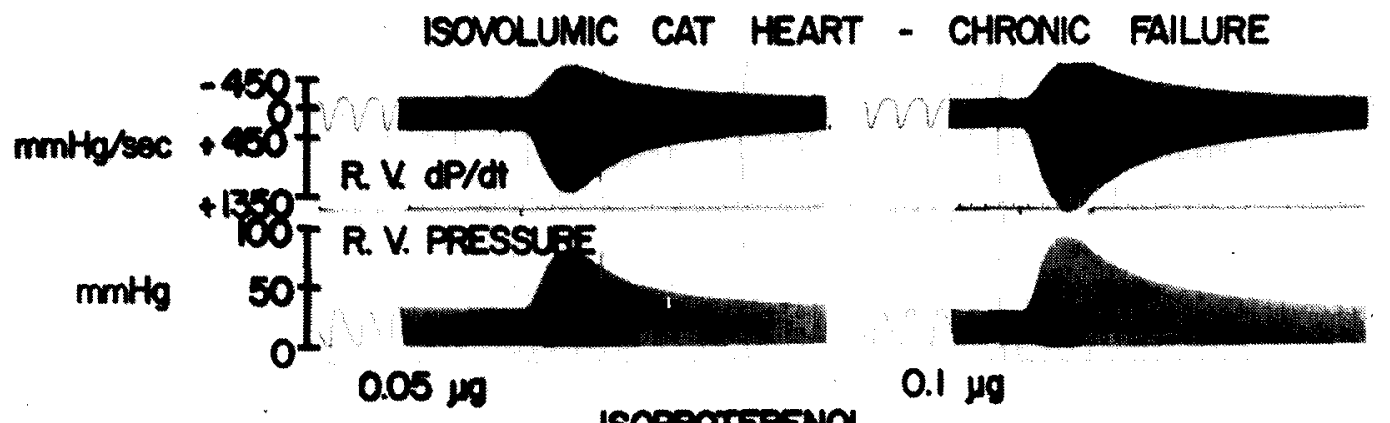

ISOPROTERENOL

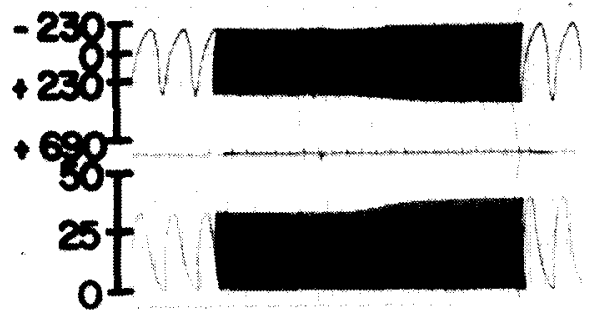

$10 \mathrm{mo}$

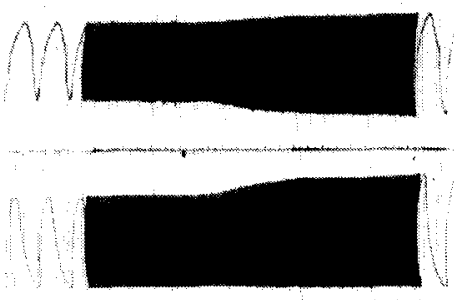

2019

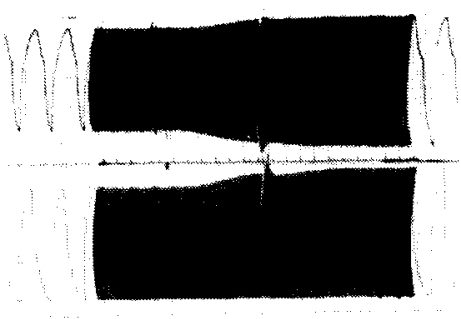

$40 \mu$

\section{GLUCAGON}

Fig. 1. A representative recording from an isovolumically beating heart obtained from a cat with chronic right ventricular failure. Right ventricular pressure, recorded from an isovolumic intraventricular balloon and rate of pressure development $(\mathrm{RV} \mathrm{dP} / \mathrm{dt})$ are shown. Heart rate was maintained constant by electrical pacing. The administration of isoproterenol and glucagon results in a positive inotropic response as evidenced by an augmentation in $\mathrm{dP} / \mathrm{dt}$ and $\mathrm{RV}$ pressure (note the change in scales between isoproterenol and glucagon). Perfusion pressure was maintained constant at $90 \mathrm{~mm} \mathrm{Hg}$. The doses of glucagon represent cumulative doses with each succeeding injection being made when the previous dose had reached its peak value.

\section{Discussion}

In an effort to resolve the question concerning the therapeutic efficacy of glucagon in the chronically failed heart, several studies were undertaken to examine the possibility that chronic cardiac failure itself might alter the responsiveness of the heart to glucagon (Gold et al., 1970; Goldstein et al., 1971; Strauer, 1971; Prasad, 1972). Studies on isolated papillary muscles obtained from cats with experimentally induced right ventricular failure and humans with chronic heart failure led Gold et al. (1970) and Goldstein et al. (1971) to conclude that the chronic heart failure state diminishes the effectiveness of glucagon as an inotropic agent. Furthermore, studies by Levey et al. (1970) suggested that chronic heart failure interferes with the mechanisms by which glucagon acts to enhance the activity of myocardial adenylate cyclase even though norepinephrine retained its ability to increase adenyl cyclase activity. These findings offered a tentative explanation as to why chronic cardiac failure in man may be associated with a marked impairment of the capacity of glucagon to augment myocardial contractility.

Recently, Timmis et al. (1973) have reported on the efficacy of prolonged glucagon administration in the management of $10 \mathrm{pa}$ tients with chronic congestive heart failure, 9 of whom were noted to improve upon administration of the hormone. Similar clinical observations have been reported by Lvoff and Wilcken (1972). These clinical results are not in accordance with previous laboratory studies 
(Gold et al., 1970; Goldstein et al., 1971; Prasad, 1972). Recently reported observations from this laboratory (Nobel-Allen et al., 1973) have demonstrated that glucagon is capable of augmenting cardiac function in the anesthetized cat in which chronic right ventricular failure had developed subsequent to the banding of the pulmonary artery. The present study confirms these earlier observations and the use of the cat isolated, isovolumic heart circumvents many of the criticisms which may be raised with respect to an evaluation of myocardial function in the intact animal. The use of the perfused isolated isovolumic heart eliminates many of the variables such as changes in heart rate, preload and afterload. Furthermore, the perfused heart in contrast to the isolated papillary muscle, derives its nutritional and oxygen supplies via the vascular bed rather than by diffusion across the cells. This latter point may be of extreme significance when one considers the fact that the hypertrophy which results in the chronically failed heart may offer a barrier to diffusion particularly to large molecules such as glucagon. On the other hand, smaller molecules like norepinephrine may be affected not at all or to a lesser degree. Although the data are contrary to previous studies in cat isolated papillary muscles (Gold et al., 1970), the discrepancy may be related to the fact that the perfused cat heart may be more responsive to the positive inotropic action of glucagon. Tuttle (1970) has reported that cat papillary muscles are significantly less reponsive to the stimulating action of the hormone as compared to papillary muscle from the canine heart. The cat isolated papillary muscle may become totally unresponsive to glucagon when one superimposes an intrinsic defect in contractility by subjecting the ventricle to a chronic pressure load.

\section{References}

Beck, L., 1958, Automatic blood pressure stabilizer and volume recorder, Univ. Mich. Med. Bull. 24, 118.
Brogan, E., M.C. Kozonis and D.C. Overy, 1969, Glucagon therapy in heart failure, Lancet 1, 482 .

Farah, A. and R. Tuttle, 1960, Studies on the pharmacology of glucagon, J. Pharmacol. Exptl. Therap. 129,49 .

Glick, G., W.W. Parmley, A.S. Wechsler and E.H. Sonnenblick, 1968, Glucagon: Its enhancement of cardiac performance in the cat and dog and persistence of its inotropic action despite $\beta$-receptor blockade with propranolol, Circulation Res. 22, 789 .

Gold, H.K., K.H. Prindle, G.S. Levey and S.E. Epstein, 1970, Effects of experimental heart failure on the capacity of glucagon to augment myocardial contractility and adenyl cyclase, J. Clin. Invest. $49,999$.

Goldstein, R.E., C.L. Skelton, G.S. Levey, D.L. Glancy, G.D. Beiser and S.E. Epstein, 1971, Effects of chronic heart failure on the capacity of glucagon to enhance contractility and adenyl cyclase activity of human papillary muscles, Circulation 44 , 638.

Greenberg, B.H., A.G. Tsakiris, E.A. Moffitt and R.L. Frye, 1970, The hemodynamic and metabolic effects of glucagon in patients with chronic valvular disease, Mayo Clin. Proc. 45, 132.

Levey, G.S., K.H. Prindle, Jr. and S.E. Epstein, 1970, Effects of glucagon on adenyl cyclase activity in the left and right ventricles and liver in experimentally produced isolated right ventricular failure, $\mathrm{J}$. Mol. Cell. Cardiol. 1, 403.

Lucchesi, B.R., 1968, Cardiac actions of glucagon, Circulation Res. 22, 777.

Lvoff, R. and D.E.L. Wilcken, 1972, Glucagon in heart failure and in cardiogenic shock, Circulation 45,534 .

Nobel-Allen, N., M. Kirsch and B.R. Lucchesi, 1973, Glucagon: Its enhancement of cardiac performance in the cat with chronic heart failure, J. Pharmacol. Exptl. Therap. 187, 475.

Prasad, K., 1972, Effect of glucagon on the transmembrance potential, contraction, and ATP-ase activity of the failing human heart, Cardiovasc. Res. 6, 684 .

Siegel, J.H., M.J. Levine, R. McConn and L.R.M. DelGuercio, 1970, The effects of glucagon infusion on cardiovascular function in the critically ill, Surg. Gyn., Obst. 131, 505.

Smithen, C.S., R. Balcon and E. Sowton, 1972, Effects of glucagon on left ventricular function in man with controlled heart rate, Cardiol. 57, 311.

Spann, J.F., Jr., R.A. Buccino and E.H. Sonnenblick, 1967, Production of right ventricular hypertrophy with and without congestive heart failure in the cat, Proc. Soc. Exptl. Biol. Med. 125, 522.

Strauer, B.E., 1971, The influence of glucagon on myocardial mechanisms of papillary muscles ob- 
tained from patients with chronic congestive heart failure, Naunyn-Schmiedeb. Arch. Pharmacol. 270, 90.

Timmis, G.C., R. Lin, R.G. Ramos and S. Gordon, 1973, Prolonged glucagon infusion in cardiac failure, J. Amer. Med. Assoc. 223, 293.

Tuttle, R.R., 1970, Comparative action of glucagon and catecholamines in the heart, Federation Proc. 29,611 .
Vaughn, C.C., H.R. Warner and R.M. Nelson, 1970, Cardiovascular effects of glucagon following cardiac surgery, Surg. 67, 204.

Wilcken, D.E.L. and R. Lvoff, 1970, Glucagon in resistant heart-failure and cardiogenic shock, Lancet 1, 1315.

Williams, J.F., Jr., R.H. Childress, J.N. Chip and J.F. Border, 1969, Hemodynamic effects of glucagon in patients with heart disease, Circulation $39,38$. 